\title{
Biomarker responses of Nile Tilapia (Oreochromis niloticus) exposed to polluted water from Kelani river basin, Sri Lanka: Implications for biomonitoring river pollution
}

\author{
K. M. Sudesh Ruvinda and Asoka Pathiratne* \\ Department of Zoology and Environmental Management, University of Kelaniya, Kelaniya, GQ \\ 11600, Sri Lanka \\ *Correspondence (asoka@kln.ac.lk) \\ iD https://orcid.org/0000-0002-2961-9064
}

\begin{abstract}
Biomarkers can be considered as early warning signals for potential adverse effects on the biota. The present study examined the feasibility of using selected biomarker responses of a model fish, Oreochromis niloticus under laboratory exposure approach for identification of potential biological impacts of pollution in Kelani River. Laboratory acclimated $O$. niloticus were exposed under static-renewal conditions to water samples collected from selected sites of the Kelani River basin with different anthropogenic influences and biomarker responses (brain and muscle cholinesterase activities for neurotoxicity, erythrocyte micronuclei and nuclear abnormalities for genotoxicity and liver histology for hepatic damage) were evaluated at 5 and 10 days of exposure. Exposed water was physico-chemically characterized using standard analytical methods. The results revealed that exposure of $O$. niloticus to the water from selected polluted sites which included canals and canal confluences resulted in significant increases $(\mathrm{p}<0.05)$ in total erythrocyte nuclear abnormalities, evolution of erythrocyte micronuclei and induction of liver histopathological indices in comparison to the fish exposed to the water from the upper reach of the river (reference site) in most cases and the control fish exposed to the aged tap water in all cases. Brain cholinesterase activity was significantly inhibited $(\mathrm{p}<0.05)$ in the fish exposed to the water from the most polluted site compared to the control fish exposed to the aged tap water. Biomarker responses indicated that the fish populations inhabiting the polluted sites in the river may be under stress especially due to hepatic damage and genotoxicity. Evaluation of "effect directed biomarker responses" of the model fish, O. niloticus following laboratory exposure to the contaminated water can be a practically feasible approach for biomonitoring potential pollution impacts associated with the riverine ecosystems.
\end{abstract}

Keywords: biomarker; biomonitoring; Kelani River; pollution; tilapia

\section{INTRODUCTION}

Contamination of riverine ecosystems with high levels of anthropogenic pollutants could deplete their resource values and create unintended irreversible damages to the biota (Pan et al. 2016). In line with the sustainable development goals, potential biological impacts of river pollution should be identified in order to implement effective strategies for management and conservation of these water resources. Conventional monitoring approach focusing on a selected set of physico-chemical factors and pollutant levels do not completely provide information on the ecological conditions under which organisms live in the ecosystems. Examining biomarkers which could reflect the interactive effects of all contaminants on impaired biological processes in exposed organisms is a promising and cost effective approach for assessing biological impacts of aquatic pollution (van der Oost et al. 2003; Colin et al. 2016). In aquatic ecosystems, use of multi-biomarkers in fish at different levels of biological organization (molecular/biochemical, cellular, tissue/organ levels etc.) may give a more reliable picture of the pollution impacts (Ballesteros et al. 2017; Vieira et al. 2017). Inhibition of acetyl cholinesterase enzyme activities in fish can affect proper neurotransmission at cholinergic synapses. Hence, cholinesterase (ChE) in fish has been recognized as a promising biomarker at molecular/biochemical level for neurotoxic contaminations in the water bodies (van der Oost et al. 2003; Pathiratne et al. 2008). Erythrocytic micronuclei and nuclear abnormalities in fish are 
cellular level biomarkers for assessing genotoxic effects (Al-Sabti and Metcalfe 1995; Hemachandra and Pathiratne 2016, 2017). The liver is a vital organ and analysis of liver histological alterations in fish can be used as a tissue level biomarker for assessing organ damage (Pathiratne et al. 2010; Ghisi et al. 2016; Kumar et al. 2017).

Kelani River which receives complex mixtures of pollutants from multiple sources is considered as the most polluted river in Sri Lanka considering diverse industrial and urban waste inputs (Ileperuma 2000; Bandara 2003; Mahagamage and Manage 2014). Although water quality of Kelani River has been assessed extensively using conventional monitoring methods (Silva 1996; Mahagamage et al. 2014), scientific reports on the impacts of river pollution on biota are limited. Use of biomarker responses in native fish populations inhabiting Kelani River would be an effective strategy for biological impact assessments. However, use of native fishes which are being exposed naturally to pollution loads in the riverine ecosystem may not be feasible in some situations where same species may not be able to capture from all the study sites for comparison of biomarker responses. In such situations, biological impacts may be assessed using easily available model fish species exposed to contaminated water under laboratory conditions. Nile tilapia (Oreochromis niloticus) is a well-established model organism for toxicological studies under tropical conditions. The objective of the present study was to examine the feasibility of using "effect directed biomarker responses" of Nile tilapia for assessing potential biological impacts of Kelani River pollution by laboratory exposure approach. The examined biomarkers were brain and muscle cholinesterase activities for neurotoxicity, erythrocyte micronuclei and nuclear abnormalities for genotoxicity and liver histology for hepatic damage.

\section{MATERIALS AND METHODS}

\section{Test fish}

Fingerlings of $O$. niloticus were obtained from Udawalawa fish breeding station of the National Aquaculture Development Authority of Sri Lanka. Fish were acclimated to the laboratory conditions for two weeks under natural photoperiod in fiberglass tanks filled with continuously aerated aged tap water. Fish were daily fed with commercially available fish food pellets (Prima food, Ceylon Grain Elevators Limited, Sri Lanka) at 2\% body weight. During the acclimation period, half of the water in the tanks was renewed every two days with aged tap water. General water quality parameters of the fish rearing tanks were measured daily and were within desirable limits for fish (temperature: $27-29^{\circ} \mathrm{C} ; \mathrm{pH}$ : 6.5-7.5; dissolved oxygen concentration: $5.5-6.5 \mathrm{mg}$ $\mathrm{L}^{-1}$; conductivity: $80-90 \mu \mathrm{S} \mathrm{cm}{ }^{-1}$; total dissolved solids: $\left.38-40 \mathrm{mg} \mathrm{L}^{-1}\right)$.

\section{Water sampling sites}

Four water sampling sites (Sites A, B, C and R) in the Kelani River basin (Figure 1) were selected based on the anthropogenic pollution sources. Maha Ela (6 $6^{\circ} 57^{\prime} 29.43^{\prime \prime} \mathrm{N}$ and $\left.79^{\circ} 59^{\prime} 34.85^{\prime \prime} \mathrm{E}\right)$ is a polluted canal with the industrial, agricultural and urban waste in the Gampaha District which eventually converges with the Kelani River close to a water extraction point of the National Water Supply and Drainage Board for treatment and distribution to general public. The Site A is located in Maha Ela where another canal (Menikagara Ela) that drains the downstream from export promotion industrial zone at Biyagama joins with Maha Ela. The Site B is the confluence of Maha Ela with the Kelani River (6 $6^{\circ} 56^{\prime} 18.59^{\prime \prime} \mathrm{N}$ and $\left.79^{\circ} 58^{\prime} 8.18^{\prime \prime} \mathrm{E}\right)$. The Site $\mathrm{C}$ is located in the down reaches (at Sedawatta) of the Kelani River in the Colombo District (6 $6^{\circ} 7^{\prime} 14.67^{\prime \prime} \mathrm{N}$ and $\left.79^{\circ} 53^{\prime} 22.71^{\prime \prime} \mathrm{E}\right)$ where Kittampahuwa Ela carrying contaminants from different sources (including oil installation complex effluents, urban runoff and household waste) confluence with the River. The upper reach of Kelani River at Ruwanwella ( $7^{\circ} 2^{\prime} 38.8^{\prime \prime} \mathrm{N}$ and $80^{\circ} 15^{\prime} 6.4^{\prime \prime}$ E) was selected as the reference site (Site R), considering relatively less anthropogenic pollution sources.

The sampling of water was carried out on several occasions in September 2015. On each occasion, surface water samples were taken from randomly selected three sub-sampling sites to represent a particular site. Water samples were transported to the laboratory for fish exposure study which was commenced on the first day of water collection. In each occasion, equal volumes of water from each sub sampling sites were mixed together to make a 
composite sample to represent the respective sampling site for fish exposure studies.

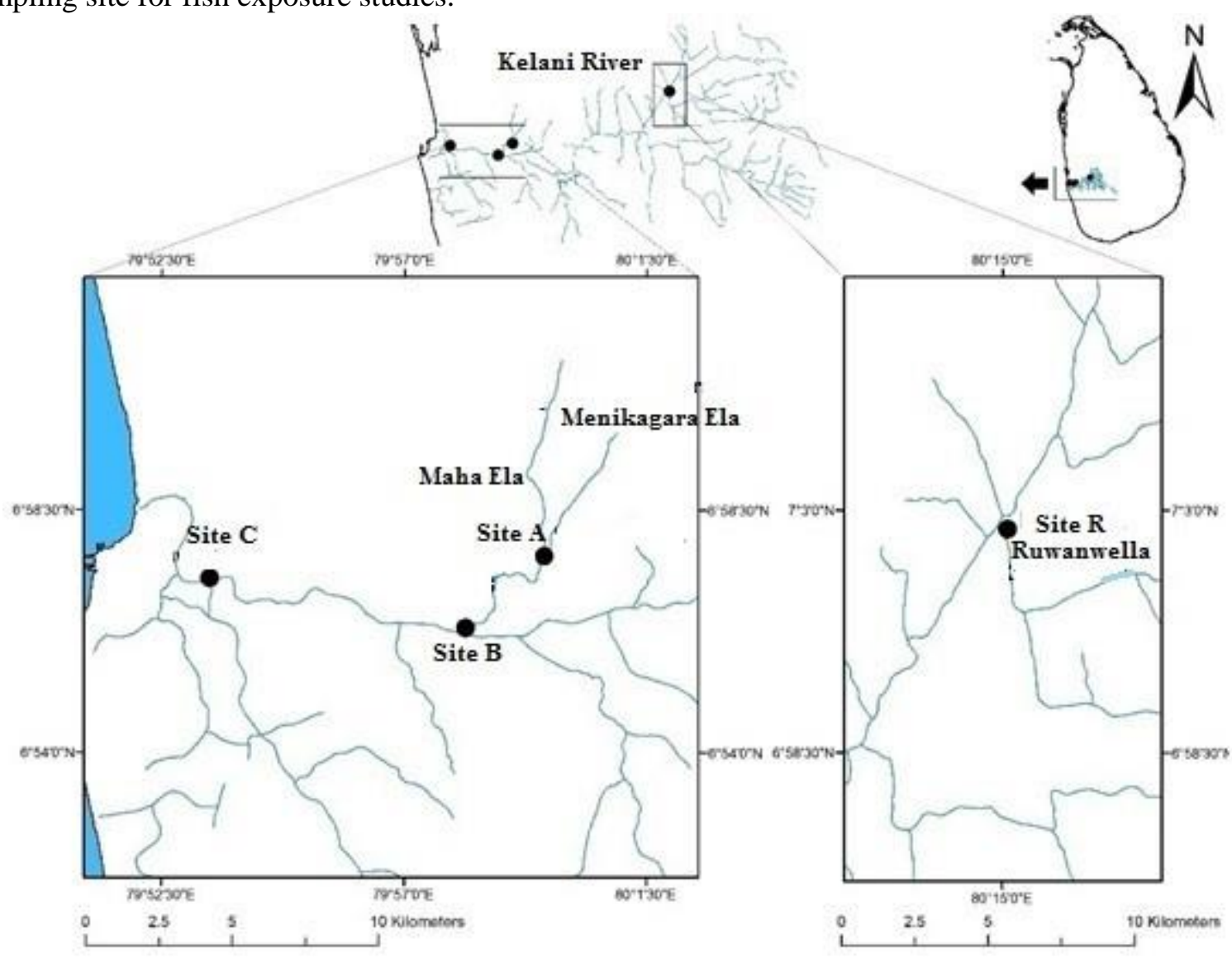

Figure 1 Water sampling sites in the Kelani river basin, Sri Lanka (Sites A, B, C and R)

Physico-chemical characterization of surface water

In situ surface water physico-chemical parameters in each sub-site viz. temperature, $\mathrm{pH}$, conductivity, salinity and total dissolved solids were measured using calibrated multi-probe water quality checker (YSI/Model: 556 MPS, USA). For analysis of other parameters, water samples from each site were collected into clean glass stoppered bottles (for total phosphate and nitrate analysis), dark glass stoppered bottles (for biochemical oxygen demand analysis) and acid washed polypropylene bottles with screw caps (for heavy metal analysis) as appropriate. Water samples were transported to the laboratory under chilled condition and refrigerated at $4^{\circ} \mathrm{C}$ until analysis.
Biochemical oxygen demand $\left(\mathrm{BOD}_{5}\right)$ (Method $5210 \mathrm{~B}$ ), chemical oxygen demand (COD) (Method 5220B), total phosphate concentration (Persulfate Digestion Method 4500-P B.5), total nitrate content (cadmium reduction method $4500 \mathrm{NO}_{3}^{-}-\mathrm{E}$ ) in the water samples were analyzed as described in APHA (1998). Selected heavy metal levels ( $\mathrm{Cd}, \mathrm{Cr}, \mathrm{Cu}, \mathrm{Pb}$ and $\mathrm{Zn}$ ) in the water samples were analyzed using atomic absorption spectrophotometry (graphite furnace mode) (Analytik Jena: Model novAA400P) following APHA (1998). Samples, which were previously preserved using concentrated ultra-pure nitric acid were analyzed for metals within one month. Standard solutions were prepared from the commercial reference solutions (Reagecon Diagnostics Limited, Ireland) for each metal separately. The sum of mean and ten times the 
standard deviation of blank values was taken as the limit of quantification (LOQ) for each metal.

\section{Laboratory exposure of the test fish to river water}

Fingerlings of Nile tilapia (9 to $13 \mathrm{~cm}$ in total length) which had been acclimated to the laboratory conditions were exposed to the water sampled from the Sites A, B, C and R separately in glass tanks (15 $\mathrm{L}$ ) in duplicates ( $\mathrm{n}=7$ fish per tank) for 10 days under static renewal conditions. Concurrently the fishes in another two sets of tanks $(\mathrm{n}=7$ fish per tank) were maintained in the aged tap water (control). The exposure media were moderately aerated. Physico-chemical characteristics of the aged tap water used for exposure studies were also determined as described above. In each tank, water was renewed after two days with freshly sampled river water from each site or aged tap water as appropriate. Fish were not fed during the five days' exposure period. After 5 days of exposure, five fish representing each exposed water type were sampled randomly from the two replicate tanks for biomarkers studies. Remaining fish were maintained under static renewal exposure conditions with moderate feeding and five fish were sampled again on the $10^{\text {th }}$ day for the biomarker studies. All fish survived at the end of the exposure period. International ethical guidelines in relation to animal care and experimentation were followed in the bioassay.

The sampled fishes were immediately sacrificed individually under an overdose of anaesthesia (70 $\mathrm{mg} \mathrm{L}^{-1}$ Benzocaine). Blood was drawn from the caudal vein of each fish on to a glass slide and a thin smear of blood was prepared, air-dried and processed further for assessment of erythrocytic nuclear abnormalities. Brain and a piece of muscle tissue closer to the anterior margin of the dorsal fin were dissected out and stored in ultra-low temperature freezer at $-80^{\circ} \mathrm{C}$ until processed for $\mathrm{ChE}$ assay. Pieces of liver tissue were preserved in $10 \%$ neutral buffered formalin for histological studies.

\section{Determination of ChE activity}

Frozen brain and muscle tissues were thawed in an ice bath. The tissues (20 mg from each tissue) of each fish were homogenized separately in $1 \mathrm{~mL}$ of ice-cold $0.1 \mathrm{M}$ NaHPO$/ \mathrm{Na}_{2} \mathrm{HPO}_{4}$ buffer using
Ultra Turrax T25 tissue homogenizer (IKA Labortechnik, Germany) at high speed for 45 seconds. Cholinesterase activity in each tissue homogenate was determined by a colorimetric method (Ellman et al. 1961) as a kinetic assay with acetyl thiocholine iodide as the substrate using a computer-controlled spectrophotometer (GBC Cintra 10e, Australia). ChE activity was calculated using the extinction coefficient of 5, 5'-dithiobis-2nitrobenzoate ion $\left(13600 \mathrm{M}^{-1} \mathrm{~cm}^{-1}\right)$. The total protein contents in brain and muscle homogenates were determined by the colorimetric method of Lowry et al. (1951) using bovine serum albumin as the protein standard.

\section{Assessing erythrocyte nuclear abnormalities}

The blood smears were fixed with absolute methanol and stained with 5\% Giemsa stain. Excess stain was washed with $50 \%$ methanol and occurrence of micronuclei and other nuclear abnormalities (if any) in at least 1000 mature erythrocytes per slide were examined using the binocular light microscope (Olympus-21FS1, Malaysia) under $1000 \mathrm{X}$ magnification. Blind scoring of nuclear abnormalities was performed on coded slides without knowledge of the origin of the samples. Small non-refractive ovoid membranebound chromatin bodies showing the same staining pattern as the main nucleus and focusing on the same plane as the nucleus were considered as micronuclei (Al-Sabti and Metcalfe 1995). Other nuclear abnormalities were classified as described earlier (Hemachandra and Pathiratne 2016, 2017). The results are expressed as number of abnormalities in a particular category as well as the total nuclear abnormalities per 1000 erythrocytes.

\section{Assessing liver histological structure}

Preserved liver samples were processed using the standard histological procedures with paraffin embedding technique. The sections were cut at $5 \mu \mathrm{m}$ thickness and stained with haematoxylin and eosin. Coded slides were examined under the binocular light microscope (Olympus-21FS1, Malaysia) for identification of different categories of liver histopathological (if any) conditions (circulatory changes, regressive changes, progressive changes and inflammation etc.) as described by Bernet et al. 
(1999). An importance factor (W) was assigned to each alteration ranging from 1 to 3 . Every alteration was assessed using a score value $(a)$ ranging from 0 to 6 , depending on the degree and the extent of the alteration; 0 unchanged; 2 mild occurrence; 4 moderate occurrence; and 6 severe occurrence, intermediate values also given as appropriate. Randomly selected ten areas of the liver tissue were analyzed and the liver histopathological index (I) was calculated for each fish using the equation, $I=$ $\sum(a \times \mathrm{W})$ where, $I=$ histopathological index, $a=$ score value for specific reaction pattern, $\mathrm{W}=$ importance factor specific reaction pattern (Bernet et al. 1999).

\section{Data analysis}

All the data are presented as mean \pm SEM. The data were analyzed using one-way analysis of variance test (ANOVA). Before analysis, nuclear abnormality data were transformed to Arc-Sine (Zar 1998). Other data were transformed to $\log _{10}(X+1)$ scale where appropriate. If there were significant differences, Tukey's test was used for comparison of means. The accepted level of significance was $\mathrm{p}<0.05$.

\section{RESULTS}

Of the measured physico-chemical parameters (Table 1), conductivity, TDS and COD levels in the water collected from the Sites A, B, and C were significantly higher $(p<0.05)$ than those in the Site $\mathrm{R}$ (reference site) and aged tap water (control). Moreover, the highest conductivity, TDS, $\mathrm{BOD}_{5}$, $\mathrm{COD}$, total $\mathrm{PO}_{4}{ }^{3-}$ and $\mathrm{NO}_{3}{ }^{-}$levels were found in the water collected from the Site A $(p<0.05)$. The water from the Sites $\mathrm{B}$ and $\mathrm{C}$ also contained comparatively high levels of total $\mathrm{PO}_{4}{ }^{3-}$ and $\mathrm{NO}_{3}$. All the measured heavy metals in the Site $\mathrm{R}$ water were below the detection limits. All the measured heavy metals (cadmium, chromium, lead and zinc) were detected in the water collected from the Sites A. Water samples from the Site B also contained detectable levels of cadmium and chromium.
Chromium was also detected in the water samples collected from the Site C. Copper was not detected (LOQ: $7 \mu \mathrm{g} \mathrm{L}^{-1}$ ) in any of the water samples tested.

Cholinesterase activities (Table 2) of the brain tissue of $O$. niloticus exposed to the water from Site A were significantly lower $(\mathrm{p}<0.05)$ compared with the fish exposed to the aged tap water (control) at 5 days' exposure (24\% inhibition). However, muscle $\mathrm{ChE}$ activities did not show significant differences among the treatments ( $p>0.05$ ). Erythrocytic nuclear abnormalities observed in the blood of exposed fish were micronuclei, nuclear buds, blebbed nuclei, notched nuclei and vacuolated nuclei (Figure 2). Micronucleated erythrocytes were observed only in the fish exposed to the water samples from Sites A and C at both exposure periods (Table 3). Total nuclear abnormalities in the erythrocytes of the fish exposed to the water from the Sites A, B and C were significantly higher than those of the control fish $(\mathrm{p}<0.05)$ in both exposure periods (Table 3 ). No significant differences in the occurrence of total nuclear abnormalities were noted between the control fish and the fish exposed the water from the Site R (reference site).

Liver tissues of $O$. niloticus exposed to aged tap water (controls) exhibited normal polygonal shaped hepatocytes and sinusoids (Figure 3). The fish exposed to the water samples collected from the study sites showed alterations in the liver histology (Figure 3). The most prominent categories were circulatory disturbances (i.e. sinusoid congestion), regressive changes (i.e increased vacuolations in the hepatocytes, pycnotic nuclei and focal necrosis in the parenchyma) and inflammatory changes (i.e leukocyte infiltration). Fish exposed to the water from the Sites A, B, C and R showed significant increases in liver histopathological indices (Table 4) compared to the fish exposed to the aged tap water (control fish). However, the liver damage was higher in the fish exposed to the water from the Sites A, B and C compared to the Site R (reference site). At 10 days exposure, the severity of liver damage was the highest in the fish exposed to Site $\mathrm{C}$ water. 
Table 1 Physico-chemical characteristics of the water used for exposure of $O$. niloticus under laboratory conditions

\begin{tabular}{|c|c|c|c|c|c|}
\hline Parameter & $\begin{array}{l}\text { Aged tap } \\
\text { water }\end{array}$ & Site $\mathrm{R}$ water & Site A water & Site B water & Site $\mathrm{C}$ water \\
\hline Temperature $\left({ }^{\circ} \mathrm{C}\right)$ & $29.1 \pm 0.1^{\mathrm{a}}$ & $26.6 \pm 0.3^{\mathrm{b}}$ & $30.3 \pm 0.1^{\mathrm{a}}$ & $29.1 \pm 0.3^{\mathrm{a}}$ & $29.1 \pm 0.9^{\mathrm{a}}$ \\
\hline $\mathrm{pH}$ & $7.6 \pm 0.1^{\mathrm{a}}$ & $7.4 \pm 0.2^{\mathrm{a}}$ & $7.6 \pm 0.1^{\mathrm{a}}$ & $7.5 \pm 0.1^{\mathrm{a}}$ & $7.6 \pm 0.1^{\mathrm{a}}$ \\
\hline Salinity $\left(\mathrm{g} \mathrm{L}^{-1}\right)$ & $0.0 \pm 0.0^{\mathrm{a}}$ & $0.0 \pm 0.0^{\mathrm{a}}$ & $0.7 \pm 0.3^{\mathrm{a}}$ & $0.4 \pm 0.2^{\mathrm{a}}$ & $0.1 \pm 0.0^{\mathrm{a}}$ \\
\hline Conductivity $\left(\mu \mathrm{S} \mathrm{cm}^{-1}\right)$ & $8 \pm 3^{a}$ & $38 \pm 1^{b}$ & $1688 \pm 506^{d}$ & $292 \pm 44^{\mathrm{c}}$ & $180 \pm 46^{c}$ \\
\hline $\operatorname{TDS}\left(\mathrm{mg} \mathrm{L}^{-1}\right)$ & $2 \pm 0.5^{\mathrm{a}}$ & $19 \pm 0.3^{b}$ & $1116 \pm 163^{d}$ & $489 \pm 339^{c}$ & $83 \pm 12^{\mathrm{c}}$ \\
\hline $\mathrm{DO}\left(\mathrm{mg} \mathrm{L}^{-1}\right)$ & $6.7 \pm 0.2^{\mathrm{ab}}$ & $8.0 \pm 0.4^{\mathrm{a}}$ & $5.7 \pm 1.1^{\mathrm{ab}}$ & $4.9 \pm 0.3^{\mathrm{b}}$ & $7.2 \pm 0.4^{\mathrm{ab}}$ \\
\hline $\mathrm{BOD}_{5}\left(\mathrm{mg} \mathrm{L}^{-1}\right)$ & $0.6 \pm 0.2^{\mathrm{a}}$ & $1.7 \pm 0.3^{\mathrm{b}}$ & $13.5 \pm 1.0^{c}$ & $1.5 \pm 0.3^{\mathrm{b}}$ & $3.2 \pm 1.5^{\mathrm{b}}$ \\
\hline $\mathrm{COD}\left(\mathrm{mg} \mathrm{L}^{-1}\right)$ & $4 \pm 1^{\mathrm{a}}$ & $9 \pm 2^{\mathrm{a}}$ & $186 \pm 9^{c}$ & $56 \pm 8^{\mathrm{b}}$ & $75 \pm 14^{b}$ \\
\hline $\mathrm{PO}_{4}^{3-}\left(\mathrm{mg} \mathrm{L}^{-1}\right)$ & ND & $\mathrm{ND}$ & $1.17 \pm 0.15^{b}$ & $0.15 \pm 0.03^{\mathrm{a}}$ & $0.12 \pm 0.05^{\mathrm{a}}$ \\
\hline $\mathrm{NO}_{3}^{-}\left(\mathrm{mg} \mathrm{L}^{-1}\right)$ & ND & $0.61 \pm 0.10^{\mathrm{a}}$ & $26.40 \pm 0.46^{b}$ & $2.23 \pm 0.76^{\mathrm{a}}$ & $6.43 \pm 1.73^{\mathrm{c}}$ \\
\hline $\mathrm{Cd}\left(\mu \mathrm{g} \mathrm{L}{ }^{-1}\right)$ & $<0.2$ & $<0.2$ & $12 \pm 2^{\mathrm{a}}$ & $12 \pm 3^{\mathrm{a}}$ & $<0.2$ \\
\hline $\mathrm{Cr}\left(\mu \mathrm{g} \mathrm{L}^{-1}\right)$ & $<2$ & $<2$ & $5 \pm 1^{b}$ & $3 \pm 1^{\mathrm{ab}}$ & $2 \pm 0^{\mathrm{a}}$ \\
\hline $\mathrm{Cu}\left(\mu \mathrm{g} \mathrm{L}^{-1}\right)$ & $<7$ & $<7$ & $<7$ & $<7$ & $<7$ \\
\hline $\mathrm{Pb}\left(\mu \mathrm{g} \mathrm{L}^{-1}\right)$ & $<5$ & $<5$ & $16 \pm 3$ & $<5$ & $<5$ \\
\hline $\mathrm{Zn}\left(\mu \mathrm{g} \mathrm{L^{-1 }}\right)$ & $<23$ & $<23$ & $24 \pm 1$ & $<23$ & $<23$ \\
\hline
\end{tabular}

TDS: total dissolved solid; DO: dissolved oxygen; $\mathrm{BOD}_{5}$ : biochemical oxygen demand; COD: chemical oxygen demand; $\mathrm{PO}_{4}{ }^{3-}$ : total phosphate; $\mathrm{NO}_{3}{ }^{-}$: nitrate nitrogen. Data are presented as mean $\pm \mathrm{SEM}$. In a row data denoted by different superscript letters are significantly different from each other (ANOVA, Tukey's test, $p<0.05$ ). Bold numerals indicate the highest values detected. The Limit of Quantification (LOQ) (in $\mu \mathrm{g} \mathrm{L}^{-1}$ ) for $\mathrm{Cd}, \mathrm{Cr}, \mathrm{Cu}, \mathrm{Pb}$ and $\mathrm{Zn}$ are $0.2,2,7,5$ and 23 respectively; ND: Not detected.

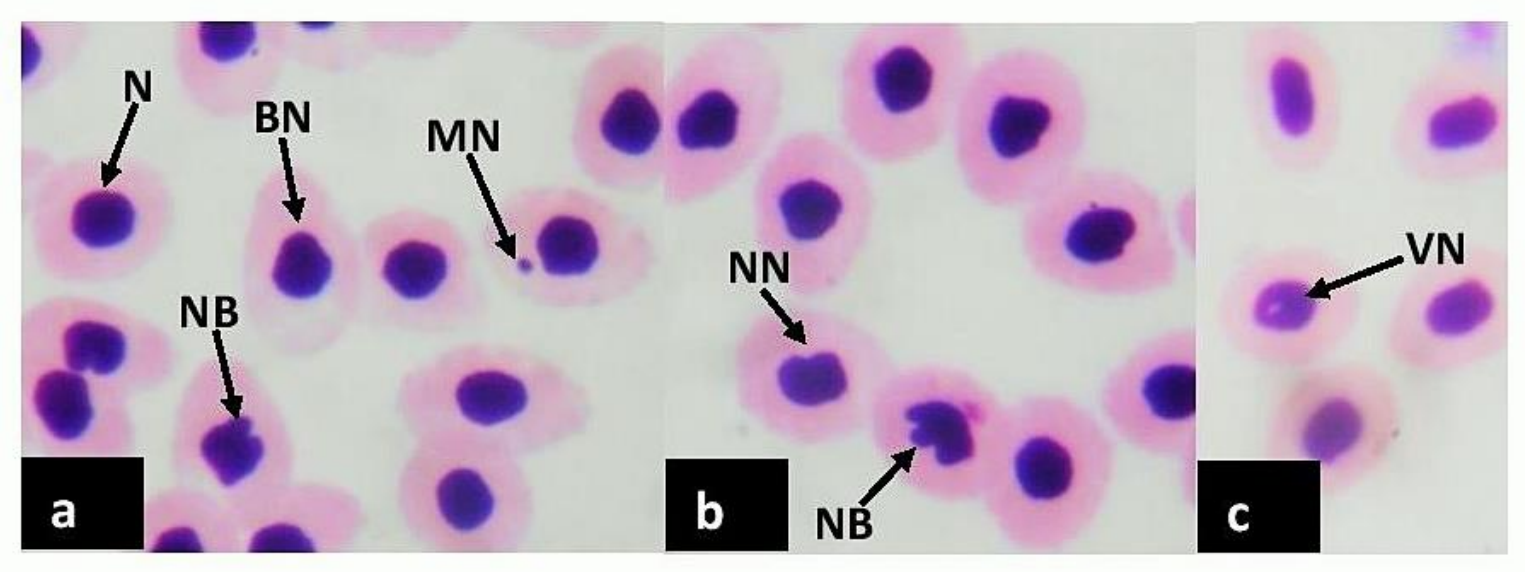

Figure 2 Blood smears of $O$. niloticus exposed to Kelani River water samples showing erythrocytes with normal nucleus $(\mathrm{N})$, micronucleus $(\mathrm{MN})$, nuclear bud $(\mathrm{NB})$, blebbed nucleus $(\mathrm{BN})$, notched nucleus $(\mathrm{NN})$ and vacuolated nucleus (VN) 
K.M.S. Ruvinda \& A. Pathiratne

Table 2 Brain and muscle cholinesterase (ChE) activities of $O$. niloticus exposed to water from selected sites of Kelani River basin

\begin{tabular}{ccc}
\hline \multirow{2}{*}{ Exposure } & \multicolumn{2}{c}{ ChE activity $\left(\mu \mathrm{mol}^{-1} \min ^{-1} \mathrm{mg}\right.$ protein $)$} \\
\cline { 2 - 3 } 5 days of exposure & Brain & Muscle \\
Aged tap water & $479 \pm 27^{\mathrm{a}}$ & $230 \pm 28^{\mathrm{a}}$ \\
Site R water & $392 \pm 54^{\mathrm{ab}}$ & $194 \pm 34^{\mathrm{a}}$ \\
Site A water & $363 \pm 22^{\mathrm{b}}$ & $179 \pm 16^{\mathrm{a}}$ \\
Site B water & $514 \pm 23^{\mathrm{a}}$ & $172 \pm 21^{\mathrm{a}}$ \\
Site C water & $461 \pm 19^{\mathrm{a}}$ & $194 \pm 12^{\mathrm{a}}$ \\
10 days of exposure & & \\
Aged tap water & $484 \pm 16^{\mathrm{a}}$ & $201 \pm 22^{\mathrm{a}}$ \\
Site R water & $544 \pm 40^{\mathrm{a}}$ & $210 \pm 8^{\mathrm{a}}$ \\
Site A water & $589 \pm 56^{\mathrm{a}}$ & $301 \pm 24^{\mathrm{a}}$ \\
Site B water & $425 \pm 28^{\mathrm{a}}$ & $231 \pm 24^{\mathrm{a}}$ \\
Site C water & $533 \pm 49^{\mathrm{a}}$ & $322 \pm 38^{\mathrm{a}}$ \\
\hline
\end{tabular}

Data are presented as mean \pm SEM $(n=5)$. In a column data denoted by similar superscript letters are significantly not different from each other $(\mathrm{p}>0.05)$

Table 3 Erythrocytic nuclear abnormalities of $O$. niloticus exposed to water from selected sites of Kelani River basin

\begin{tabular}{rcccccc}
\hline \multicolumn{1}{c}{ Exposure } & $\begin{array}{c}\text { Micro- } \\
\text { nucleus \%o }\end{array}$ & $\begin{array}{c}\text { Nuclear } \\
\text { buds \%o }\end{array}$ & $\begin{array}{c}\text { Blebbed } \\
\text { nuclei \%o }\end{array}$ & $\begin{array}{c}\text { Notched } \\
\text { nuclei \%o }\end{array}$ & $\begin{array}{c}\text { Vacuolated } \\
\text { nuclei \%o }\end{array}$ & $\begin{array}{c}\text { Total nuclear } \\
\text { abnormalities } \\
\% \text { o }\end{array}$ \\
\hline 5 days exposure & & & & & & \\
Aged Tap water & 0.0 & $1.4 \pm 0.6$ & $9.4 \pm 1.0$ & $4.8 \pm 0.9$ & 0.0 & $15.6 \pm 1.2^{\mathrm{a}}$ \\
Site R water & 0.0 & $1.8 \pm 0.4$ & $13.8 \pm 2.8$ & $7.8 \pm 2.7$ & 0.0 & $23.4 \pm 4.9^{\mathrm{ab}}$ \\
Site A water & $1.2 \pm 0.4$ & $4.8 \pm 0.8$ & $20.4 \pm 2.9$ & $9.6 \pm 2.11$ & $0.2 \pm 0.2$ & $36.2 \pm 5.7^{\mathrm{bc}}$ \\
Site B water & 0.0 & $4.6 \pm 0.5$ & $26.2 \pm 1.1$ & $9.0 \pm 3.1$ & 0.0 & $39.8 \pm 3.1^{\mathrm{c}}$ \\
Site C water & $1.2 \pm 0.3$ & $6.8 \pm 1.9$ & $30.2 \pm 3.7$ & $12.0 \pm 1.3$ & 0.0 & $50.2 \pm 6.3^{\mathrm{c}}$ \\
$\mathbf{1 0}$ days exposure & & & & & & \\
Aged Tap water & 0.0 & 0.0 & $17.6 \pm 1.7$ & $6.6 \pm 1.8$ & 0.0 & $24.2 \pm 2.2^{\mathrm{a}}$ \\
Site R water & 0.0 & $3.4 \pm 0.6$ & $16.8 \pm 2.4$ & $10.0 \pm 2.7$ & 0.0 & $30.2 \pm 4.7^{\mathrm{ab}}$ \\
Site A water & $1.4 \pm 0.3$ & $7.2 \pm 1.2$ & $19.8 \pm 4.3$ & $12.0 \pm 2.8$ & 0.0 & $40.4 \pm 3.1^{\mathrm{b}}$ \\
Site B water & 0.0 & $7.0 \pm 0.5$ & $33.2 \pm 2.2$ & $5.4 \pm 2.0$ & 0.0 & $45.6 \pm 3.1^{\mathrm{bc}}$ \\
Site C water & $0.8 \pm 0.3$ & $6.4 \pm 1.9$ & $35.8 \pm 2.6$ & $11.0 \pm 2.4$ & 0.0 & $54.0 \pm 4.5^{\mathrm{c}}$ \\
\hline
\end{tabular}

Data are presented as mean \pm SEM $(n=5)$. For a specific exposure period, total abnormalities indicated by different superscript letters are significantly different from each other $(\mathrm{p}<0.05)$ 

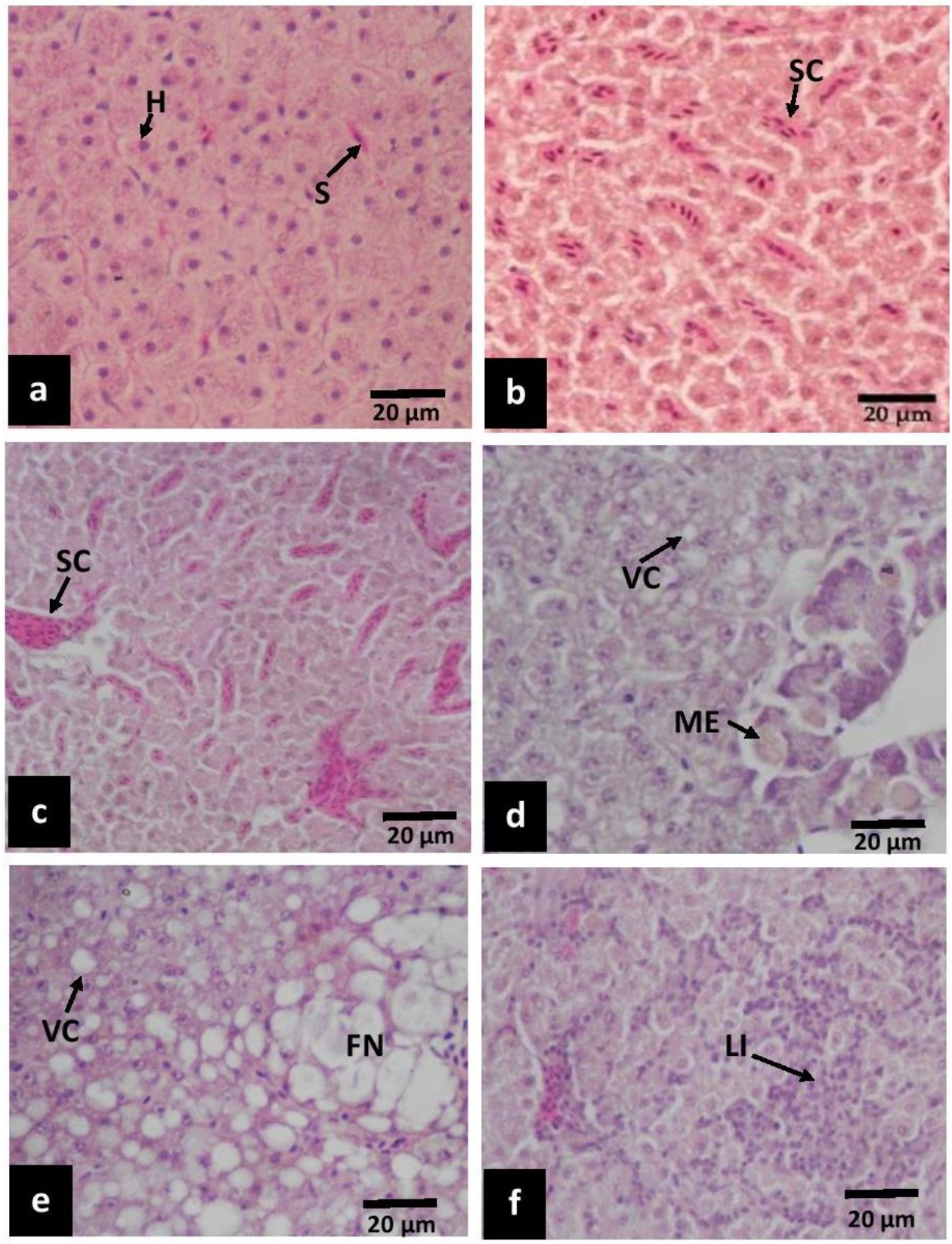

Figure 3 (a) Normal structure of $O$. niloticus liver tissue showing polygonal shaped hepatocytes $(\mathrm{H})$ and sinusoids (S); (b-f) Histological alterations seen in the livers of fish following exposure to water from selected sites in Kelani River basin: sinusoid congestion (SC), vacuolations (VC), focal necrosis (FN), melanomacrophage centres (ME) and leukocyte infiltration (LI) 
K.M.S. Ruvinda \& A. Pathiratne

Table 4 Liver histopathological indices of $O$. niloticus exposed to water from selected sites of Kelani River basin

\begin{tabular}{rcccc}
\hline Exposure & $\begin{array}{c}\text { Circulatory } \\
\text { disturbances }\end{array}$ & $\begin{array}{c}\text { Regressive } \\
\text { changes }\end{array}$ & Inflammation & $\begin{array}{c}\text { Histopathological } \\
\text { Index }\end{array}$ \\
\hline 5 days exposure & & & & \\
Aged Tap water & $2.6 \pm 0.5$ & $7.0 \pm 1.1$ & $1.2 \pm 0.8$ & $11 \pm 1^{\mathrm{a}}$ \\
Site R water & $3.4 \pm 0.9$ & $17.4 \pm 3.2$ & $2.8 \pm 1.4$ & $24 \pm 2^{\mathrm{b}}$ \\
Site A water & $7.6 \pm 1.3$ & $48.0 \pm 8.4$ & $3.2 \pm 1.9$ & $59 \pm 11^{\mathrm{c}}$ \\
Site B water & $9.6 \pm 2.1$ & $44.0 \pm 2.9$ & $2.4 \pm 1.5$ & $56 \pm 5^{\mathrm{c}}$ \\
Site C water & $7.6 \pm 1.2$ & $76.2 \pm 7.6$ & $1.2 \pm 0.8$ & $85 \pm 7^{\mathrm{c}}$ \\
$\mathbf{1 0}$ days exposure & & & & $16 \pm 2^{\mathrm{a}}$ \\
Aged Tap water & $4.0 \pm 1.1$ & $11.8 \pm 2.2$ & $0.4 \pm 0.4$ & $38 \pm 4^{\mathrm{b}}$ \\
Site R water & $6.8 \pm 0.7$ & $31.2 \pm 3.5$ & $0.4 \pm 0.4$ & $84 \pm 9^{\mathrm{c}}$ \\
Site A water & $7.2 \pm 0.8$ & $75.0 \pm 10.2$ & $1.6 \pm 1.6$ & $76 \pm 8^{\mathrm{c}}$ \\
Site B water & $9.2 \pm 2.8$ & $63.6 \pm 4.5$ & $3.6 \pm 2.4$ & $134 \pm 14^{\mathrm{d}}$ \\
Site C water & $14.4 \pm 3.1$ & $117.2 \pm 15.4$ & $2.4 \pm 0.8$ & \\
\hline
\end{tabular}

Data are represented as mean \pm SEM $(n=5)$. For a particular exposure period, histopathological indices in a column indicated by different superscript letters are significantly different from each other $(\mathrm{p}<0.05)$

\section{DISCUSSION}

Although pollution in Kelani River has been assessed using conventional monitoring methods (Silva 1996; Mahagamage et al. 2014; Mahagamage and Manage 2014), scientific reports on the biological impacts of river pollution are meagre. In the proposed 'multi-stakeholder strategy and action plan for management and conservation of the Kelani River basin 2016-2020', importance of pollution impact assessments has been emphasized (Mallawatantri et al. 2016). In line with the sustainable development goals, potential biological impacts of river pollution should be identified in order to implement effective national strategies for management and conservation of the water resources. Biomarker responses in fish are cost effective tools for monitoring and assessment of pollution impacts in riverine ecosystems (Ossana et al. 2016; Ballesteros et al. 2017). Even though the use of the biomarker responses in native fishes which are being exposed naturally to pollution loads in the riverine ecosystem over long periods is ideal for pollution impact assessments, it may not be practically feasible in some situations where same species could not be captured from all the study sites including the pristine sites for comparison of biomarker responses. As an alternate approach, we report the feasibility of using "effect-directed biomarker responses" of the model fish $O$. niloticus, for assessing potential biological impacts of Kelani river pollution by exposing the laboratory acclimated fish to polluted water collected from selected sites of the river basin.

Physico-chemical characteristics of the exposed water sampled from different sites (Table 1) of the Kelani river basin (Sites A, B, C and R) showed wide variations compared with the aged tap water (treated drinking water extracted from Kelani river). Based on $\mathrm{BOD}_{5}, \mathrm{COD}$, total phosphate, nitrate nitrogen, $\mathrm{Cd}, \mathrm{Cr}$ and $\mathrm{Pb}$ levels, overall gross pollution pattern in the study sites of the Kelani river basin followed the order: Site $\mathrm{R}<$ Site $\mathrm{C} \leq$ Site $\mathrm{B}<$ Site A. The Site A is located in Maha Ela which confluence with Menikagara Ela that drains the downstream from the industrial zone at Biyagama. Highest conductivity, TDS, $\mathrm{BOD}_{5}, \mathrm{COD}$, total phosphate, nitrate nitrogen, $\mathrm{Cr}, \mathrm{Pb}$ and $\mathrm{Zn}$ levels found in the water samples taken from this study site may be associated with the wastewater inputs through the Manikagara Ela. Relatively high conductivity, TDS, COD, total phosphate and $\mathrm{Cr}$ levels in water from the Sites B and C also indicate pollution inputs from different sources. The Site B 
is the confluence of Maha Ela with the Kelani River whereas the Site $\mathrm{C}$ is located in the down reaches (at Sedawatta) of the Kelani River where Kittampahuwa Ela carrying contaminants from different sources (including oil installation complex effluents, urban-runoff, and household waste) confluence with the river. Comparatively low levels of general pollution indicative parameters in the water from the upper reach at Ruwanwella (Site R) may indicate favourable water quality for native fish populations in the reference site. However, as the study sites in Kelani river basin are lotic habitats, their physico-chemical composition could be varied with time depending on numerous factors such as the inputs of pollutants from multiple sources, dilution effect due to the rainfall and concentration effect due to the evapotranspiration.

Biomarker responses at different levels of biological organization give complementary information in monitoring studies to better appraise how stressors affect aquatic ecosystems (Colin et al. 2016). Cholinesterase in the fish $O$. niloticus can be used as a biochemical biomarker for neurotoxic contaminations such as organophosphate /carbamate insecticides and heavy metals in the aquatic environments (Pathiratne et al. 2008; Jayasundara and Pathiratne 2008; Silva and Pathiratne 2008). A significant inhibition of brain $\mathrm{ChE}$ activities in Nile tilapia has been reported following short term exposure to several textile industry effluents reaching Bolgoda North lake, Sri Lanka (Perera and Pathiratne 2010). In the present study, brain $\mathrm{ChE}$ activities of $O$. niloticus exposed to the water from the Site A of the Kelani river basin showed significant inhibition compared to the fish exposed to the aged tap water (by 24\%). The results indicate the availability of brain ChE inhibiting agents in the water of the Site A located in Maha Ela which is passing through agricultural lands in the area. Further Menikagara Ela that drains the downstream from an industrial zone confluence with Maha Ela at the Site A. Contaminations with organophosphate/carbamate insecticides from nearby agricultural lands, heavy metals and complex mixtures of pollutants from industrial discharges may have contributed to depression of brain ChE levels in $O$. niloticus experimentally exposed to the Site A water. Depression of ChE levels in the exposed fish may be considered as early warning signals for possible neurotoxic impacts posed by the contaminants on native fish populations inhabiting this area.

Erythrocytic micronuclei and other nuclear abnormalities in fish have been used as cellular level biomarkers for assessing cytogenotoxic impacts under short term exposure to the industrial effluents (Hemachandra and Pathiratne 2016, 2017). Ossana et al. (2016) have found significant increases in total erythrocyte nuclear abnormalities in Cnesterodon decemmaculatus following short term laboratory exposure to the water of Reconquista river in Argentina. Induction of micronuclei indicates genotoxic effects which may eventually lead to malignancy (Hintzsche et al. 2017). Micronuclei are formed by both clastogenic substances which induce breaks and produce alterations in the chromosome structure and aneugenic substances which induce alterations in chromosome distribution during the cell division process giving rise to aneuploidies (Heddle et al. 1991). In the present study, $O$. niloticus exposed to the water from the Sites A and C showed induction of micronucleated cells indicating potential mutagenic hazards to biota. The significant increase $(\mathrm{p}<0.05)$ in total nuclear abnormalities found in the erythrocytes of $O$. niloticus exposed to the water from the Sites A, B and C compared to the control fish indicates the presence of genotoxic pollutants in the river water at these sites. The induction of total nuclear abnormalities was greater in the fish exposed to the Site $\mathrm{C}$ water indicating greater genotoxic potential in this site. Induction of erythrocytic micronuclei and other nuclear abnormalities in $O$. niloticus exposed to the water from these sites indicate cytogenotoxic impacts. Genotoxic stress on fish populations residing these sites may eventually lead to accumulation of mutations, accelerated aging of cells and ineffective adaption to changing environmental conditions.

Histopathological biomarkers are valuable as early indicators of the biological damage in fish as they reflect the effects of exposure to a variety of anthropogenic pollutants (Pathiratne et al. 2010; Kumar et al. 2017). The liver is the main site of biotransformation of foreign chemicals that enter the fish body. In the present study, the liver tissue of $O$. niloticus exposed to polluted water from the study sites showed structural alterations including sinusoid congestion, hepatocytes with cytoplasmic vacuolations, focal necrosis, increase in 
melanomacrophage centers and leucocyte infiltrations (Figure 3). Such structural alterations in the liver could lead to serious health implications under long term exposure. In general, histopathological conditions in the liver tissues was severe in $O$. niloticus exposed to the Site $\mathrm{C}$ water. Moreover, liver histopathological indices of the fish exposed to the water from the selected sites of Kelani river basin (Sites R, A, B and C) were increased compared to those in the control fish. Based on the liver histopathological indices of the fish which had been exposed for 10 days, the hepatic damage potential of the exposed water could be ranked as Site $\mathrm{R}<$ Site $\mathrm{A} \leq$ Site $\mathrm{B}<$ Site $\mathrm{C}$ where Site $\mathrm{C}$ water reflects more hazardous potential. The significant increase in the histopathological indices in the fish exposed to the Site R (reference site) water compared to those in the control fish indicates that the Site $\mathrm{R}$ is not a pristine area. Induction of liver histological alterations in the model fish exposed to these study sites may be considered as early warning signals for potential hepatic damage in the native fish populations chronically exposed to pollutants in the sites.

In conclusion, the present study demonstrates the sensitivity of the tested "effect directed biomarkers" of the model fish $O$. niloticus to assess pollution impacts in Kelani river. Depression of brain ChE activities, induction of erythrocyte micronuclei/nuclear alterations and hepatic tissue alterations in $O$. niloticus exposed to the polluted water from Kelani river basin can be considered as early warning signals for possible ecological impacts pose by the contaminants on native fish populations. Biomarker responses indicate that the fish populations inhabiting the polluted sites in the river may be under stress especially due to hepatic damage and genotoxicity. Continuous genotoxic stress on native fish populations may lead to accumulation of mutations, accelerated aging of cells and ineffective adaption to changing environmental conditions. Evaluation of "effect directed biomarker responses" of the wide spread model fish, $O$. niloticus following laboratory exposure to the contaminated water can be a practically feasible approach for biomonitoring potential pollution impacts associated with the riverine ecosystems. This approach would be especially useful as an alternative when native fish species could not be used in the riverine pollution impact assessments due to practical issues such as capturing difficulties, low abundance, habitat preferences and conservation status of these fishes. Effect directed biomarker responses in easily available model fish species may possibly be used as cost effective tools for identifications of potential biological hazards of river pollution in order to implement effective strategies for management and conservation of the water resources.

\section{Acknowledgements}

This research was funded by the National Research Council of Sri Lanka (Research grant 11-11) and National Science Foundation of Sri Lanka (Equipment grant RG/2011/EQ/16). Thanks are due to Mr. Harsha P. Weerarathna (Technical Officer) for the technical assistance given in the metal analysis using atomic absorption spectrometry.

\section{REFERENCES}

Al-Sabti, K. and C.D. Metcalfe 1995. Fish Micronuclei for assessing genotoxicity in water. Mutation Research 343: 121-135. https://doi.org/10.1016/0165-1218(95)90078-0

APHA AWWA WPCF 1998. Standard methods for the examination of water and wastewater, 20th ed. American Publication of Health Association, Washington, DC.

Ballesteros, M.L., N.G. Rivetti, D.O. Morillob, L. Bertrand, M.V. Amé and M.A. Bistoni 2017. Multi-biomarker responses in fish (Jenynsia multidentata) to assess the impact of pollution in rivers with mixtures of environmental contaminants. Science of the Total Environment 595: 711-722.

https://doi.org/10.1016/j.scitotenv.2017.03.203

Bandara, N.J.G.J. 2003. Water and wastewater related issues in Sri Lanka. Water Science and Technology 47: 305-312.

Bernet B, H. Schmidt, W. Meier, P. Burkhrdt-Holm and T. Wahli 1999. Histopathology in fish: proposal for a protocol to assess aquatic pollution. Journal of Fish Diseases 22: 25-34. DOI: 10.1046/j.1365-2761.1999.00134.x

Colin, N., C. Porte, D. Fernandes, C. Baratac, F. Padrósd, M. Carrassónd, M. Monroy, O, CanoRocabayera, A.D. Sostoa, B. Piña and A. Maceda-Veiga 2016. Ecological relevance of 
biomarkers in monitoring studies of macroinvertebrates and fish in Mediterranean rivers. Science of the Total Environment 540: 307-323. https://doi.org/10.1016/j.scitotenv.2015.06.099

Ellman, G.L., K.D. Courtney, V. Andres and R.M. Featherstone 1961. A new and rapid colorimetric determination of acetylcholinesterase activity. Biochemical Pharmacology 7: 88-95. https://doi.org/10.1016/0006-2952(61)90145-9

Ghisi, N.C., E.C. Oliveira, T.F.M. Mota, G.V. Vanzetto, A.A. Roque, J.P. Godinho, F.L. Bettim, H.C.D. Assis and A.J. Prioli 2016. Integrated biomarker response in catfish Hypostomus ancistroides by multivariate analysis in the Pirapó River, Southern Brazil. Chemosphere 161: 69-79.

DOI: 10.1016/j.chemosphere.2016.06.113

Heddle, J.A., M.C. Cimino, M. Hayashi, F. Romagna, M.D. Shelby, J.D. Tucker, P. Vanparys and J.J. MacGregor 1991. Micronuclei as an index of cytogenic damage: past, present and future. Environmental Molecular Mutagenesis 18: 277-291.

DOI: $10.1002 / \mathrm{em} .2850180414$

Hemachandra, C.K. and A. Pathiratne 2016. Combination of physico-chemical analysis, Allium cepa test system and Oreochromis niloticus erythrocyte based comet assay/nuclear abnormalities tests for cyto-genotoxicity assessments of treated effluents discharged from textile industries. Ecotoxicology and Environmental Safety 131: 54-64.

DOI: 10.1016/j.ecoenv.2016.05.010

Hemachandra, C.K. and A. Pathiratne 2017. Bioassessment of the effluents discharged from two export oriented industrial zones located in Kelani river basin, Sri Lanka using erythrocytic responses of the fish, Nile Tilapia (Oreochromis niloticus). Bulletin of Environmental Contamination and Toxicology 99: 481-487. DOI: 10.1007/s00128-017-2156-9

Hintzsche, H., U. Hemmann, A. Poth, D. Utesch, J. Lott and H. Stopper 2017. Fate of micronuclei and micronucleated cells. Mutation Research 771: 85-98. DOI: 10.1016/j.mrrev.2017.02.002

Ileperuma, O.A. 2000. Environmental pollution in Sri Lanka: A review. Journal of National Science Foundation of Sri Lanka 28(4): 301-325. http://doi.org/10.4038/jnsfsr.v28i4.2644
Jayasundara, V.K. and A. Pathiratne 2008. Effect of repeated application of fenthion as a mosquito larvicide on Nile tilapia (Oreochromis niloticus) inhabiting selected water canals in Sri Lanka. Bulletin of Environmental Contamination and Toxicology 80: 374-377. DOI: 10.1007/s00128008-9392-y

Kumar, N., K.K. Krishnania, S.K. Guptab and N.P. Singha 2017. Cellular stress and histopathological tools used as biomarkers in Oreochromis mossambicus for assessing metal contamination. Environmental Toxicology and Pharmacology 49: 137-147. https://doi.org/10.1016/j.etap.2016.11.017

Lowry, H., N.J. Rosenbrough, A.L. Farr and R.J. Randall 1951. Protein measurement with the folin phenol regent. Journal of Biological Chemistry 193: 265-275.

Mahagamage, M.G.Y.L., S.D.M. Chinthaka and P.M. Manage 2014. Multivariate analysis of physico-chemical and microbial parameters of surface water in Kelani river basin. International Journal of Multidisciplinary Studies 1(1): 55-61.

Mahagamage, M.G.Y.L. and P.M. Manage 2014 Water quality index (CCME-WQI) based assessment study of water quality in Kelani river basin, Sri Lanka. Proceedings of the 1st Environment and Natural Resources International Conference (ENRIC2014) 6-7 November 2014, pp. 199-204. The Sukosol hotel, Bangkok, Thailand.

Mallawatantri, A, A. Rodrigo and K. De Silva 2016. Medium to long-term multi stakeholder strategy and action plan for management and conservation of Kelani river basin. Central Environment Authority and International Union for the Conservation of Nature Sri Lanka Country Office, Colombo

Ossana, N.A., B.L. Eissa, F.G. Baudou, P.M. Castañé, S. Soloneski and L. Ferrari 2016. Multibiomarker response in ten spotted livebearer fish Cnesterodon decemmaculatus (Jenyns 1842) exposed to Reconquista river water. Ecotoxicology and Environmental Safety 133: 73-81. DOI: 10.1016/j.ecoenv.2016.06.046

Pan, B., J. Yuan, X. Zhang, Z. Wang, J. Chen, J. Lu, W. Yang, Z. Li, N. Zhao and M. Xu 2016. A review of ecological restoration techniques in fluvial rivers. International Journal of Sediment Research 31: 110-119. 
https://doi.org/10.1016/j.ijsrc.2016.03.001

Pathiratne, A., L.W.H.U. Chandrasekera and P.K.C. De Seram 2008. Effects of biological and technical factors on brain and muscle cholinesterases in Nile tilapia, Oreochromis niloticus: Implications for biomonitoring neurotoxic contaminations. Archives of Environmental Contamination and Toxicology 54: 309-317. DOI: 10.1007/s00244-007-9025-1

Pathiratne, A., K.A.S. Pathiratne and P.K.C. De Seram 2010. Assessment of biological effects of pollutants in a hyper eutrophic tropical water body, Lake Beira, Sri Lanka using multiple biomarker responses of resident fish, Nile tilapia (Oreochromis niloticus). Ecotoxicology 19: 1019-1026. DOI: 10.1007/s10646-010-0483-2

Perera, B.I.G. and A. Pathiratne 2010. Multiple biomarker responses of Nile tilapia (Oreochromis niloticus) exposed to textile industry effluents reaching Bolgoda North Lake, Sri Lanka. Sri Lanka Journal of Aquatic Sciences 15: $1-11$.

http://dx.doi.org/10.4038/sljas.v15i0.5445
Silva, E.I.L. 1996. Water quality of Sri Lanka: A review on twelve water bodies. Institute of Fundamental Studies, Kandy, Sri Lanka. 43 p.

Silva, K.T.U. and A. Pathiratne 2008. In vitro and in vivo effects of cadmium on cholinesterases in Nile tilapia fingerlings: implications for biomonitoring aquatic pollution. Ecotoxicology 17: 725-731. DOI: 10.1007/s10646-008-0221-1

Van der Oost, R., J. Beyer and N.P.E. Vermeulan 2003. Fish bioaccumulation and biomarkers in environmental risk assessment: a review. Environmental Toxicology and Pharmacology 13: 57-149. DOI: $10.1016 / \mathrm{S} 1382-6689(02) 00126-6$

Vieira, C.E.D., P.G. Costa, L.C. Cabrera, E.G. Primel, G. Fillmann, A. Bianchini, C.B.R. Martinez 2017. A comparative approach using biomarkers in feral and caged Neotropical fish: Implications for biomonitoring freshwater ecosystems in agricultural areas. Science of the Total Environment, 586: 598-609. https://doi.org/10.1016/j.scitotenv.2017.02.026

Zar, J. H. 1998. Biostatistical Analysis. Prentice Hall, Upper Saddle River, NJ, 663p 